\title{
Accumulation of Soluble Proteins and Nitrogenous Compounds in the Leaf of Bright and Burley Tobaccos during the Growing Season*
}

$b y$

R. H. Lowe

U.S. Department of Agriculture, Science and Education Administration, Lexington, Kentudey, U.S.A.

and

S. J. Sheen

Department of Plant Pathology, University of Kentucky, Lexington, Kentudky, U.S.A.

\section{INTRODUCTION}

One unique feature of tobacco, Nicotiana tabacum L., is the crystallization of Fraction I protein (FI protein) from leaf extract $(3,9)$. FI protein accumulates inside the diloroplasts of all green plants, but this water-soluble protein in plant species other than those within the genus Nicotiana cannot be readily isolated and is nearly impossible to crystallize. Approximately $50 \%$ of the soluble proteins in tobacco leaf is FI protein, which contains high concentrations of essential amino acids and is free of contaminants such as heavy metals, carbohydrates, lipids and other macromolecules (7). These chemical properties point to its pharmaceutical potential. Nutritional studies of tobacco FI protein showed a PER (protein efficiency ratio) greater than that of casein, a recognized protein standard (5). It has been suggested, therefore, that tobacco leaf protein is a potential source of protein, sufficient for meeting a health dietary demand of an increasing world population (12).

The remaining half of the soluble proteins in tobacco leaf is known as Fraction II protein (FII protein) which is highly heterogeneous in molecular weight and demical composition (13). The nutritional value of FII protein is reportedly comparable to that of FI protein (Wildman, private communication). In addition, insoluble proteins exist as sediments in the juice of tobacco leaf homogenate. Wildman (12) estimated a yield of $3,000 \mathrm{~kg}$ of soluble and insoluble proteins per hectare of tobacco employing high plant density and multiple harvests. With this cultural method, plants are harvested at a height of 45 to $50 \mathrm{~cm}$ and at 6-week intervals through a 6 to 8-month growing season.

Questions arise as to the amount of protein which may be produced per hectare and at what growth stage leaves would accumulate proteins, FI protein in particular, to

* Received: 27th May 1991 - accepred: 10th December 1981. a maximal level if tobacco plants were grown according to conventional cultural practices. Answers to these questions bear significantly on the feasibility of producing tobacco proteins commercially for human consumption and medicinal usage. We carried out such field experiments with two tobacco cultivars representing bright and Burley types during the 1977 and 1978 growing seasons. Experiments were carried out with Burley cultural practices, whereby the rate of nitrogen fertilization was not a limiting factor for protein biosynthesis. In addition, the quantitative changes of other nitrogenous compounds were analyzed for their possible relationships to protein metabolism.

\section{MA'TERIALS AND METHODS}

The tobacco cultivars NC95 and Ky14, representing bright and Burley types, respectively, were grown on the Agricultural Experiment Station Farm of the University of Kentucky in Lexington in 1977 and 1978. Conventional cultural methods for Burley tobacco were followed, where 2.24 metric tons of 5-10-5 (N-P-K) fertilizer supplemented with $320 \mathrm{~kg}$ of ammonium nitrate was disked into one hectare of land prior to transplant. This provided $224 \mathrm{~kg}$ of nitrogen per hectare. Field layouts followed a randomized blodk design with three replications for both years. Row width was $107 \mathrm{~cm}$, and plants. within a row were $46 \mathrm{~cm}$ apart. However, the 1977 experiment had 20 plants per row while there were 30 plants in the 1978 experiment.

Six weeks after transplant, middle-stalk leaves were picked and bulked on a row basis. In 1977, sampling began on July 11 and continued thereafter at 2-week intervals until the time of topping (Aug. 22). In the time between topping and harvesting (Sept. 19), leaves from top, middle, and bottom stalk positions were harvested 
Figure 1. Change of proteln quantity in the leaf of NC95 during the 1977 and 1978 growing seasons. Leaves from top, middle and bottom stalk positions are indicated by the respective symbols of $T, M$ and $B$.

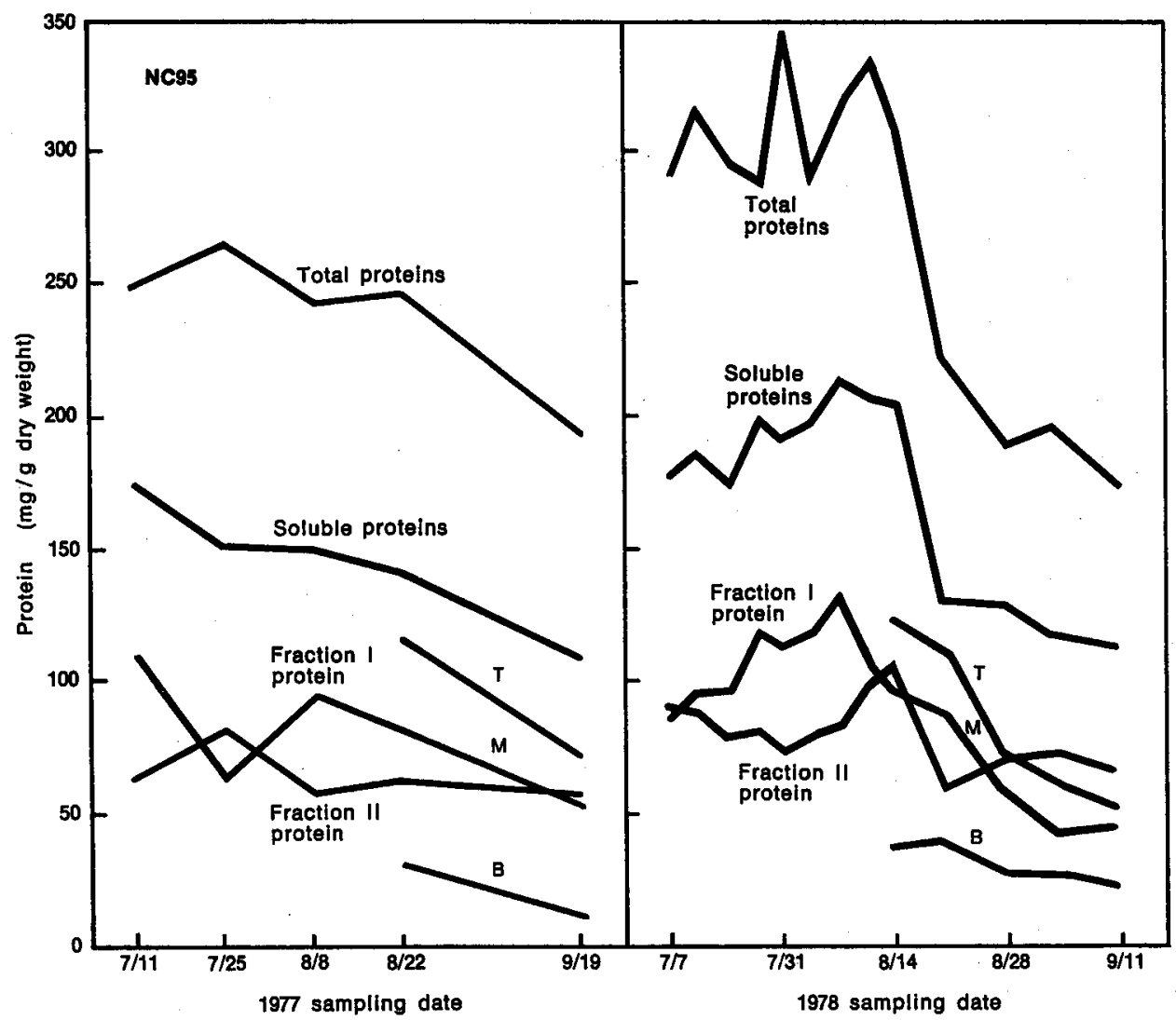

Figure 2. Change of proteln quantity in the leaf of Ky14 during the 1977 and 1978 growing seasons. Leaves from top, middle and bottom stalk positions are indicated by the respective symbols of $T, M$ and $B$.

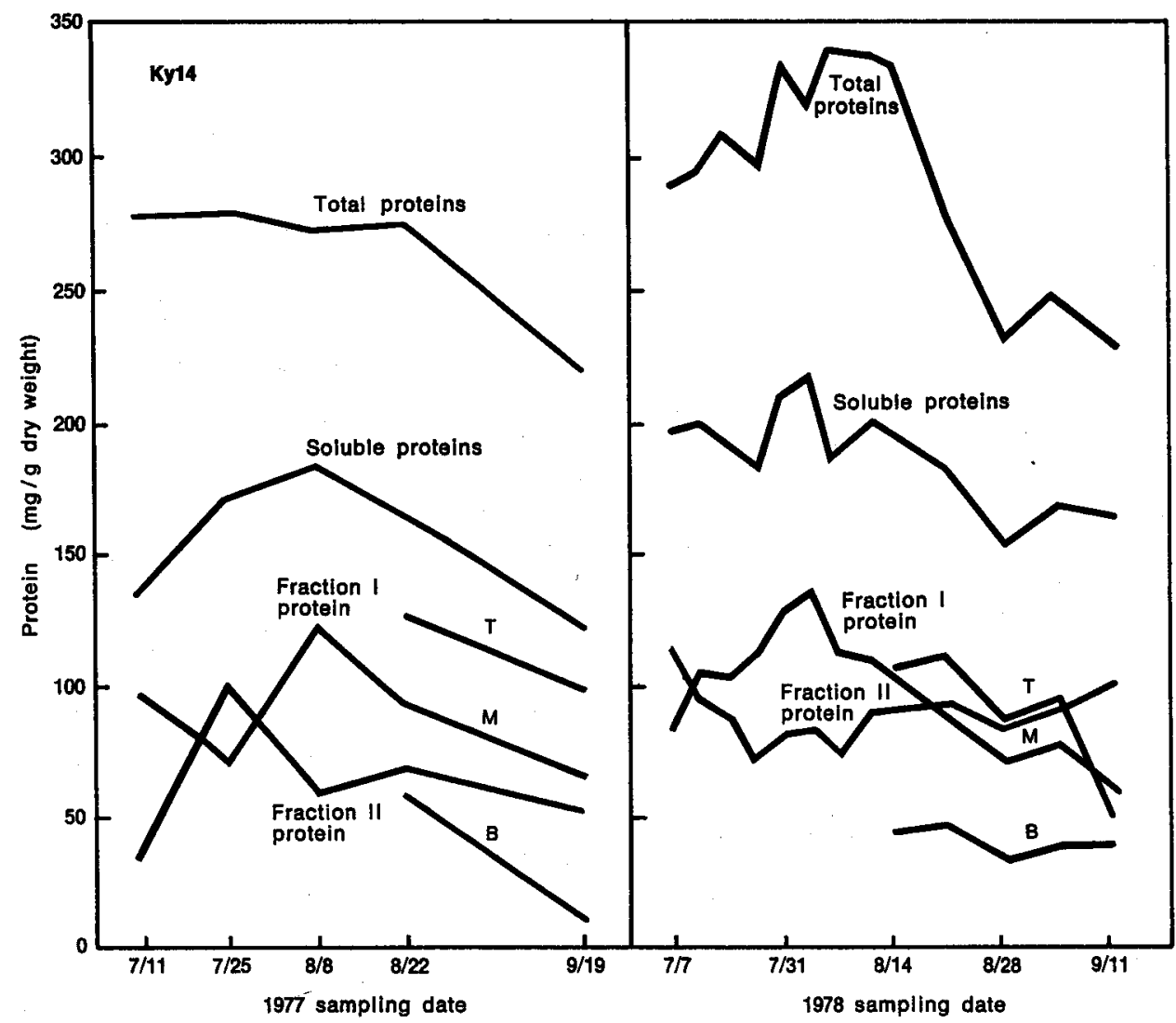


separately, i.e. on five sampling dates during the 1977 growing season. The 1978 experiment was sampled 13 times beginning on July 17 ( 6 weeks after transplant). Middle-stalk leaves were taken twice a week up to topping time (Aug. 14). From topping to harvest (Sept. 11), leaves were classified according to three stalk positions as in the previous year, except that sampling was carried out every week.

Fresh leaf samples were transported from the field to the laboratory in ice chests. After removal of the midribs, the half-leaves of each row were sampled for four leaf discs (5 cm diameter) per leaf panel for protein quantification. The opposite half-leaves were freeze-dried for determination of dry weight and the quantity of other nitrogenous constituents. Fresh leaf discs were ground with $0.5 \mathrm{~g}$ of acid-washed sand, $0.01 \mathrm{~g}$ of sodium metabisulfite and with equal amounts $(\mathrm{w} / \mathrm{v})$ of $0.125 \mathrm{M}$ TrisHCl buffer ( $\mathrm{pH} 8.5$ ) containing $1 \mathrm{M} \mathrm{NaCl}, 2 \mathrm{mM} \mathrm{MgCl} 2$ and $1 \mathrm{mM}$ disodium ethylenediaminetetracetic acid in an ice-chilled mortar. After centrifugation at $40,000 \mathrm{~g}$ for 15 minutes, the supernatant was used for quantitation of free amino acids, total soluble proteins, FI protein and FII protein. Analytical methods employing analytical ultracentrifugation and automated amino acid quantification have been detailed in a recent paper (11).

Nitrogenous constituents, namely dilorophylls, total alkaloids, total nitrogen, nitrate nitrogen, and total proteins, were quantified with the freeze-dried samples which had been pulverized to pass through a 40-mesh screen. Chlorophyll quantification was by the method of Arnon (1), whereas the amount of total alkaloids was determined colorimetrically at $460 \mathrm{~nm}$ (6). Analyses of total nitrogen, nitrate nitrogen and total proteins followed the same methods previously reported (11). Difference in quantity between total proteins and total soluble proteins gave rise to the concentration of insoluble proteins.

Data from the 1977 and 1978 experiments were treated separately for analysis of variance according to a splitplot design with cultivar as a main-plot and sampling date as a sub-plot or sampling date as a main-plot and stalk position as a sub-plot. Varietal differences in concentration of nitrogenous constituents under investigation were also evaluated by pooling two years of data after the determination of year effect and cultivar $x$ year interaction.

\section{RESULTS}

Quantitative changes of soluble and insoluble proteins in NC95 and Ky14 during the 1977 and 1978 growing seasons were determined (Figures 1 and 2, respectively). For NC95, the seasonal ranges of total protein content for the consecutive years are 193-264 and 178-338 $\mathrm{mg} / \mathrm{g}$ dry weight. 'The corresponding ranges for $\mathrm{Ky} 14$ were comparatively narrower, i.e. $220-279 \mathrm{mg} / \mathrm{g}$ dry weight in 1977 and $229-339 \mathrm{mg} / \mathrm{g}$ dry weight in 1978 . Total protein levels appeared lowest at the end of the growing season. This was consistent for both cultivars and in both years. The consistency was substantiated by the statistical insignificance of the cultivar $X$ year interaction. However, the averaged quantities of 272.9 and $294.7 \mathrm{mg} / \mathrm{g}$ dry weight for the respective cultivars in 1978 are significantly greater than the corresponding values of 239.3 and $264.8 \mathrm{mg} / \mathrm{g}$ dry weight in the previous year. Such a year effect was also evident for individual protein components. For example, the average concentrations of soluble protein varied from 147.0 to $170.5 \mathrm{mg} / \mathrm{g}$ dry weight in NC95 and from 154.7 to $188.3 \mathrm{mg} / \mathrm{g}$ dry weight in Ky14. The low protein concentration in the 1977 experiment may be explained by the fact that a wet, early growing season could leach out nitrogen in top soil, which consequently limited the protein accumulation in tobacco plants. The accumulation of soluble protein peaked around the time of topping in 1978 , but took place in the early growing season of 1977. Maximal accumulation of soluble protein coincided with the buildup of FI protein.

The pattern of FI protein accumulation showed no difference between years or tobacco cultivars. This is mirrored by the trend for the accumulation of the soluble proteins. It reached a maximal quantity about 1 to 2 weeks before topping (when $30 \%$ of the plants were flowering). This was followed by a gradual decrease in concentration. At harvest, half or more of the FI protein had disappeared. Leaf aging accompanied with a loss of FI protein was also substantiated by the results of leaf stalk positions. Young leaves from upper stalk positions were consistently greater in FI protein quantity than the leaves from lower stalk positions. The quantitative difference among stalk positions is statistically significant in most cases. In contrast, stalk positions did not affect the concentrations of F II protein and insoluble proteins. During the 1978 growing season, the maximal quantity of FII protein occurred soon after topping. Thereafter, the loss of F II protein became more rapid in NC95 than in $\mathrm{Ky} 14$, although the total loss was mud less than that of FI protein. On the other hand, the insoluble protein declined in quantity after topping and at harvest was less than $50 \%$ of its maximal quantity.

Since the 1978 growing season might be considered nor$\mathrm{mal}$ in regard to temperature and precipitation distribution, the frequent samplings of the field experiment permit a reasonable evaluation of the relationships between FI protein and FII protein and between soluble and insoluble proteins. The ratios of FI protein and FII protein averaged over all sampling dates were 1.12 and $\mathbf{1 . 1 6}$ for NC95 and Ky14, respectively. The pattern of the ratios changed in parallel with that of FI protein quantity. In other words, the ratio gradually increased during the early growing season, reached a maximal level of 1.60 to 1.70 about one week to ten days before topping, and declined to a minimal level of 0.62 to 0.68 at harvest. The latter reflects the degradation of FI protein, which, in part, stabilized the pool size of FII protein. The ratio of soluble to insoluble proteins fluctuated without a trend. Across the growing season it averaged around 1.76 for NC95 and 1.85 for Ky14. In all cases, the quantity of soluble proteins was greater than that of 


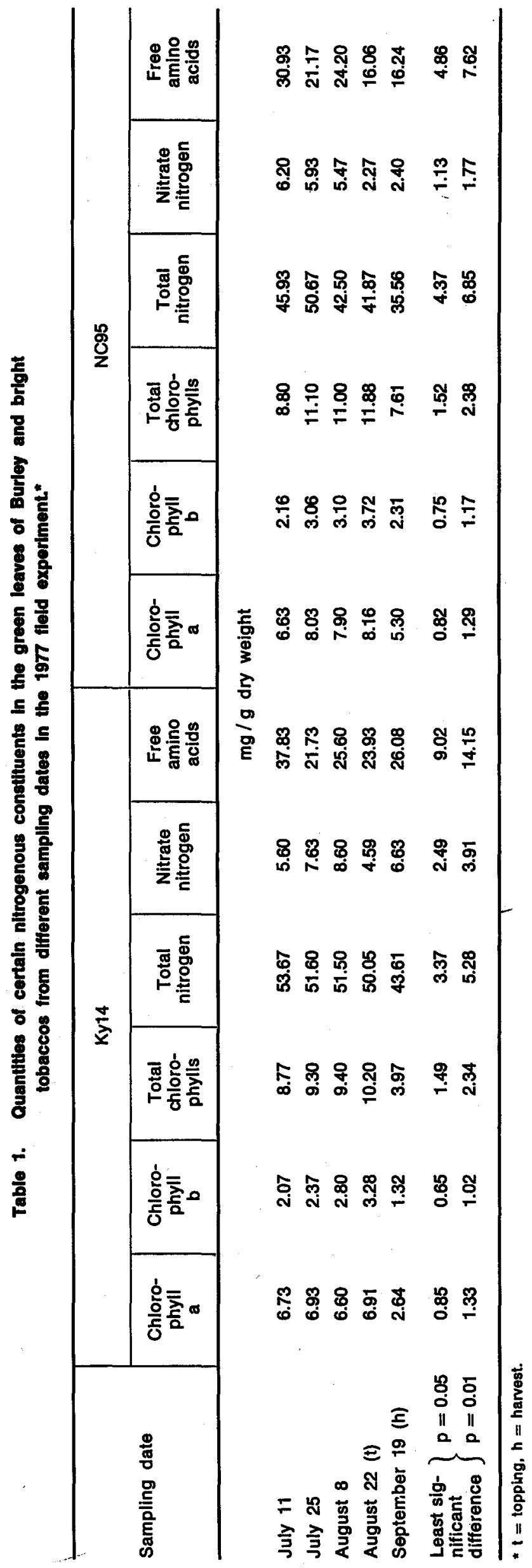




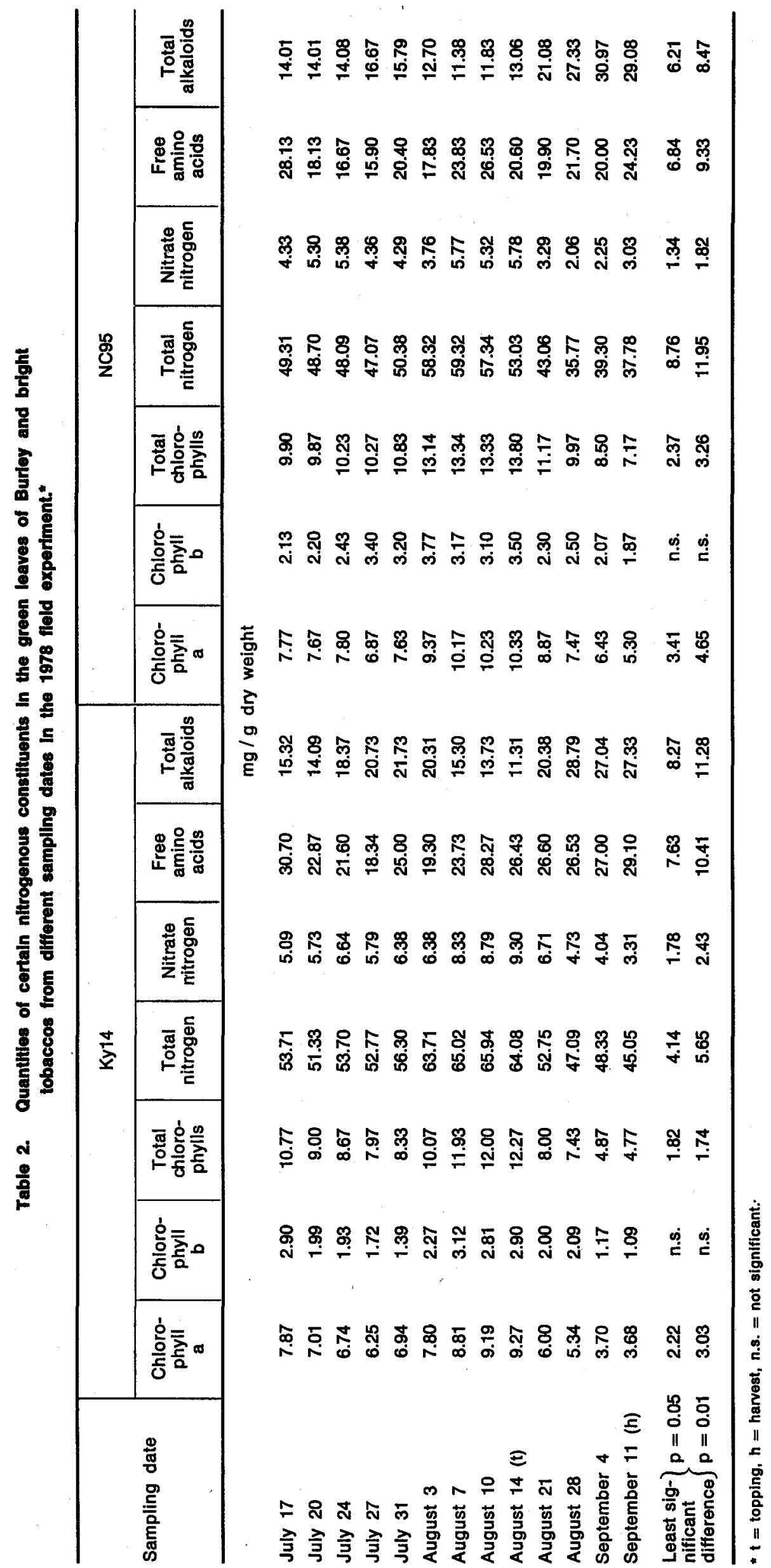


Table 4. Coefficlents of partial correlation between pairs of nitrogenous constltuents in the leaf of tobaccos cultured with Burley practices.

\begin{tabular}{|c|c|c|c|c|c|c|c|c|c|c|c|}
\hline \multicolumn{2}{|c|}{ Chemical constituent } & \multirow[t]{2}{*}{1} & \multirow[t]{2}{*}{2} & \multirow[t]{2}{*}{3} & \multirow[t]{2}{*}{4} & \multirow[t]{2}{*}{5} & \multirow[t]{2}{*}{6} & \multirow[t]{2}{*}{7} & \multirow[t]{2}{*}{8} & \multirow[t]{2}{*}{9} & \multirow[t]{2}{*}{10} \\
\hline 1 & Chlorophyil a & & & & & & & & & & \\
\hline 2 & Chlorophyll b & $0.95^{* *}$ & & & & & & & & & \\
\hline 3 & Total chlorophylls & $0.99 * *$ & $0.97^{* *}$ & & & & & & & & \\
\hline 4 & Total nitrogen & $0.60 * *$ & $0.49^{* *}$ & $0.56^{* *}$ & & & & & & & \\
\hline 5 & Nitrate nitrogen & -0.32 ** & $-0.34 * \star$ & $-0.33 * *$ & 0.14 & & & & & & \\
\hline 6 & Free amino acids & $-0.44 * *$ & $-0.46^{* *}$ & $-0.45^{* *}$ & 0.23 & 0.29 * & & & & & \\
\hline 7 & Soluble proteins & $0.64 * *$ & $0.49^{* *}$ & $0.60 * *$ & $0.78 * *$ & -0.22 & $0.31 *$ & & & & \\
\hline 8 & Fraction I protein & $0.41^{* *}$ & $0.31 *$ & 0.38 ** & $0.67 * *$ & -0.06 & 0.54 ** & $0.81 * *$ & & & \\
\hline 9 & Fraction II protein & 0.24 & 0.26 & 0.25 & $0.33^{*}$ & -0.06 & -0.22 & $0.50^{* *}$ & -0.03 & & \\
\hline 10 & Insoluble proteins & 0.29 * & 0.22 & 0.27 & 0.56 ** & 0.09 & $0.38^{* *}$ & 0.07 & 0.08 & -0.06 & \\
\hline 11 & Total proteins & $0.80 * *$ & $0.71^{* *}$ & $0.78 * *$ & $0.90^{* * *}$ & -0.13 & -0.11 & $0.88 * *$ & $0.73^{* *}$ & $0.40^{* *}$ & $0.53 * *$ \\
\hline
\end{tabular}

* and **: signiflcant difference at the $5 \%$ and $1 \%$ level of probability, respectively.

Table 5. Estimation of blomass and protein yield in immature and mature tobacco plants culfured with Burley practices.

\begin{tabular}{l|c|c|c|c|c|c|c|}
\hline \multirow{2}{*}{ Growth stage } & \multicolumn{3}{|c|}{$\begin{array}{c}\text { Number } \\
\text { of plants } \\
\text { per hectare }\end{array}$} & \multicolumn{3}{|c|}{ Blomass * } \\
\cline { 5 - 8 } & leaf lamina & midrib & whole leaf & stalk & total biomass \\
\hline
\end{tabular}

$\begin{array}{lllrrrr}\text { At kne日-height (July 20) } & 80,000 & 29,600 & 10,400 & 40,000 & 40,000 & 80,000 \\ \text { At flower bud (Aug. 3-7) } & 40,000 & 21,164 & 7.436 & 28,600 & 23,400 & 52,000 \\ \text { By harvest (Sept. 11) } & 20,000 & 11,396 & 4,004 & 15,400 & 12,600 & 28,000\end{array}$

\begin{tabular}{|c|c|c|c|c|c|}
\hline \multirow{2}{*}{ Protein } & \multirow{2}{*}{ Growth stage } & \multirow{2}{*}{ Cultivar } & \multicolumn{3}{|c|}{ Protein yield } \\
\hline & & & $\mathrm{mg} / \mathrm{g}$ dry weight & $\mathrm{mg} / \mathrm{g}$ fresh weight ** & kg/ha \\
\hline \multirow[t]{6}{*}{ Fraction I protein } & July 20 & NC95 & 95.53 & 14.30 & 423.28 \\
\hline & & Ky14 & 105.87 & 15.88 & 470.05 \\
\hline & August $3-7$ & NC95 & 131.83 & 19.78 & 418.62 \\
\hline & & Ky14 & 136.63 & 20.50 & 433.86 \\
\hline & September 11 & NC95 & 46.24 & 6.94 & 79.09 \\
\hline & & Ky14 & 63.00 & 9.45 & 107.69 \\
\hline \multirow[t]{6}{*}{ Fraction II protein } & July 20 & NC95 & 90.37 & 13.56 & 401.38 \\
\hline & & Ky14 & 94.07 & 14.11 & 417.66 \\
\hline & August $3-7$ & NC95 & 81.13 & 12.17 & 257.57 \\
\hline & & Ky14 & 80.24 & 12.04 & 254.82 \\
\hline & September 11 & NC95 & 67.53 & 10.13 & 115.44 \\
\hline & & Ky14 & 101.43 & 15.22 & 173.45 \\
\hline
\end{tabular}

\footnotetext{
- The weight distribution of leaf lamina and midrib in tobacco leaves is $74 \%$ and $26 \%$, respectively, whereas the proportions of leaf and stalk are $50 \%$ each when plants are at knee-height but $55 \%$ and $45 \%$ for the respective plant parts at the later growth stages.

** Fresh welght is calculated on the basis of $85 \%$ moisture.
} 
Table 3. Comparison of Burley and bright tobacco leaves for the quantities of protein and other nitrogenous constituents as averaged over sampling dates and two yeare.+

\begin{tabular}{l|l|l}
\hline $\begin{array}{l}\text { Chemical } \\
\text { constltuent }\end{array}$ & Ky14 & NC95 \\
\hline
\end{tabular}

$\mathrm{mg} / \mathrm{g}$ dry weight

$\begin{array}{lrc}\text { Chlorophyll a } & 5.25 & 6.67^{* *} \\ \text { Chlorophyll b } & 2.38 & 2.96^{*} \\ \text { Total chlorophylls } & 7.63 & 9.63^{* *} \\ \text { Total nitrogen } & 51.02 & 43.63^{* *} \\ \text { Nitrate nitrogen } & 6.38 & 3.75^{* *} \\ \text { Total alkaloids } & 1.95 & 1.77^{*} \\ \text { Free amino acids } & 28.03 & 21.68^{* *} \\ \text { Soluble proteins } & 165.11 & 154.63^{*} \\ \text { Fraction I protein } & 95.97 & 86.20^{* *} \\ \text { Fraction Il protein } & 75.42 & 72.55 \\ \text { Insoluble proteins } & 110.77 & 97.22^{*} \\ \text { Total proteins } & 264.40 & 241.45^{* *}\end{array}$

+ Data from mid-stalk leaves were used for all chemical constituents except the quantity of total proteins which is calculated from the results of three stalk positions. The comparison of total alkaloid quantity is based on the 1978 data only.

* and **: significant difference at the $5 \%$ and $1 \%$ level of probabliity, respectively.

insoluble proteins. This also held true in the 1977 experiment.

Nitrogenous compounds other than proteins were quantified in the 1977 experiment (Table 1). For both tobacco cultivars, dhlorophylls accumulated to maximal levels at topping followed by a gradual decline toward the end of the growing season. Quantities of total nitrogen, free amino acids and nitrate nitrogen varied among the sampling dates. All these phenomena were observed again in the 1978 experiment (Table 2). There was a trend of decreasing nitrate nitrogen toward the harvesting date, which became evident because of the frequent samplings. However, free amino acid content remained variable during the growing season. A rapid increase of alkaloids occurred after topping.

When NC95 and Ky14 were compared, by pooling two years of data together, the cultivar $X$ year interaction was not insignificant for the compounds analyzed. All nitrogenous constituents under investigation, except F II protein, showed a significant difference between NC95 and Ky14 (Table 3). The former had a high concentration of chlorophylls, which reflects its normal chlorophyll genotype. Being a chlorophyll deficient mutant, Ky14 contained more total nitrogen, nitrate nitrogen, total alkaloids, free amino acids and some protein components. The interrelationships of these nitrogenous constituents analyzed on all sampling dates of both years may be examined by the coefficients of partial correlation (Table 4). The positive significant correlations of total nitrogen with all analyzed nitrogenous constituents, except nitrate nitrogen and free amino acids, indicate that, during the growing season, the major nitrogenous compound is protein and the change of protein and chlorophyll quantity affects the total nitrogen content in the leaf. Similarly, total protein concentration showed positive correlations with protein components and chlorophylls. The latter is negatively correlated with nitrate nitrogen and free amino acids, substantiating the fact that chlorophyll content declines toward the late growing season while nitrate nitrogen and free amino acids gradually accumulate. The content of F II protein is positively correlated only with that of total nitrogen and soluble proteins.

\section{DISCUSSION}

The potential of tobacco as a food crop rests on the nutritional quality of protein, while the economics rests on biomass and protein yield per hectare. Wildman (12) suggested a direct seeding of tobacco to establish a stand of more than 370,000 plants per hectare. With multiple harvests during one growing season, this high density growth would yield about 150 metric tons of fresh biomass per hectare from which $3,000 \mathrm{~kg}$ of protein can be harvested. As to the protein, it was estimated that about $320 \mathrm{~kg}$ of crystalline FI protein and $1,300 \mathrm{~kg}$ of F II protein may be obtained. The remaining $45 \%$ of the protein is insoluble. These values far exceed the protein yield of alfalfa and soybean which reportedly yield 710 and $640 \mathrm{~kg}$ protein per hectare, per year, respectively (10). Although the present field experiments were not conducted with high plant density and multiple harvests, the results in combination with available information on the relationship between plant density and biomass in Burley tobacco (2), as illustrated in the following paragraphs, support Wildman's view that tobacco is a potential protein crop.

With the existing tobacco transplanter, the number of plants per hectare can be varied by altering row width and plant spacing within a row. In conventional Burley cultural practices (107 cm row and $46 \mathrm{~cm}$ between plants), one hectare grew 20,000 plants. The population may be doubled or quadrupled by use of $91 \mathrm{~cm}$ rows and $25 \mathrm{~cm}$ or $13 \mathrm{~cm}$ between plants. Such high plant densities are feasible if plants are harvested before blooming, when FI protein quantity is highest, or at knee-height. The estimated biomass and the yield of FI protein and F II protein at three growth stages as they represent three plant populations are summarized in Table 5. Since leaf protein concentration at a given growth stage is independent of plant density, the protein yield per hectare at a given population density was calculated on the basis of protein quantity in leaf lamina at the corresponding growth stage in the 1978 experiment. Soluble proteins in midrib and stalk were excluded. Therefore, the estimated protein yield is conservative. At the immature plant stage, one harvest would yield 824.7 and $887.7 \mathrm{~kg}$ of soluble proteins per hectare for NC95 and Ky14, respectively. Based on a previous experiment (2), two additional harvests of ratooning plants at 5 to 6 -week in- 
tervals for the remaining growing season are still possible, provided the field is fertilized and irrigated as needed. A production of more than $1,500 \mathrm{~kg}$ of soluble protein per hectare would be a realistic figure equal to, or surpassing, Wildman's estimation.

If tobacco plants were harvested one to two weeks before topping and at the time of the greatest $F I$ protein accumulation, NC95 and Ky14 could yield about $680 \mathrm{~kg}$ of soluble proteins per hectare. A harvest of regrowth would make the total protein yield comparable to alfalfa and soybean. This still does not include the insoluble proteins. The yield of soluble proteins decreased dramatically when plants approached maturity. At harvest NC95 retained only $194.5 \mathrm{~kg}$ of soluble proteins per ha, whereas Ky14 gave $281.1 \mathrm{~kg} / \mathrm{ha}$. These values are in the same magnitude as recently reported by DeJong and Lam (4). They obtained $16 \mathrm{~kg}$ of soluble proteins as a by-product of the homogenized leaf curing process (HLC) for each metric ton of fresh tobacco leaves in the flue-cured tobacco region. If leaf biomass per hectare were similar in Burley and flue-cured tobacco regions, 15.4 metric tons of leaf would yield $246 \mathrm{~kg}$ of soluble proteins. The above calculation clearly indicates that high plant density and multiple harvests at the young plant stages would be the best management for protein production in tobacco.

Differences in protein yield between NC95 and Ky14 suggest genetic variability in this agronomic character. Comparatively, Ky14 contains about $10 \%$ more soluble proteins than NC95, irrespective of the three growth stages mentioned above. When including insoluble proteins, NC95 produced $1387.4 \mathrm{~kg}$ of proteins per ha in contrast to $1307.7 \mathrm{~kg} / \mathrm{ha}$ for $\mathrm{Ky} 14$ at the immature plant stage. Both cultivars had similar levels of total protein (700.7 and $701.4 \mathrm{~kg} / \mathrm{ha}$ respectively) before flowering. At harvest, a reverse situation with more protein in $\mathrm{Ky} 14$ $(392.0 \mathrm{~kg} / \mathrm{ha})$ than in NC95 $(304.1 \mathrm{~kg} / \mathrm{ha})$ became evident. Difference in nitrogen metabolism of these tobacco types are also reflected by higher concentrations of total nitrogen and nitrate nitrogen in Ky14.

In the present study, both tobacco types were cultured according to Burley methods. In NC95, FI protein decreased, but the dilorophyll content danged very little when the leaves were maturing. Ky14 exhibited an exact reverse phenomenon for these leaf constituents. It appears that bright tobacco is comparable to or better than Burley for protein (soluble and insoluble) production at immature stages. However, a superior characteristic of bright tobacco is that it grows faster than Burley in the seedling stage. On the other hand, Burley would be better than bright tobacco in the homogenized leaf curing process (4), from which more soluble protein can be isolated from leaf juice as a by-product, and yet there would be less plastid pigments in the homogenized tobacco product.

Since Burley is a chlorophyll deficient mutant, one may ask what is the metabolic relationship between chlorophylls and soluble proteins. Can a slow accumulation of chlorophylls favor the increase of soluble proteins, FI protein in particular? It is well documented that FI pro- tein is confined within the chloroplast (7). Can the structural and/or demical modification of chloroplast limit the packing of chlorophylls but favor the accumulation of FI protein? To understand the genetic regulation of FI protein accumulation in tobacco leaf, the characterization of known chlorophyll deficient mutants in this regard should be highly appropriate and desirable. Such a study has been, therefore, conducted with pale yellow $(P y)$ and yellow green $(y g)$ genotypes in addition to Burley and dark green tobaccos. A quantitative comparison of individual and total proteins as well as other leaf chemical constituents among chlorophyll genotypes will be presented in a separate paper.

\section{SUMMARY}

Under conventional cultural practices for Burley tobacco, the pattern of soluble protein accumulation, namely Fraction I protein (FI protein) and Fraction II protein (FII protein), in bright (NC95) and Burley (Ky14) tobaccos were similar during the growing seasons of 1977 and 1978. Their quantities reached maximal levels around flowering, followed by a gradual decline. However, the loss of F I protein was much more rapid than that of F II protein during leaf maturation. The two-year results revealed that Ky14 contains significantly more FI protein, insoluble proteins, total proteins, free amino acids, total nitrogen, nitrate nitrogen and total alkaloids than NC95, if averaged over the growing season. The latter showed a greater amount of dhlorophyll only. There was no difference in FII protein concentration between the two cultivars.

On the basis of soluble protein concentration in leaf lamina and a double or quadruple plant population as plant size permits, the estimated yields of soluble proteins in Ky14 at the immature plant stage, about one week before topping, and by harvest time are 888, 470 and $281 \mathrm{~kg} / \mathrm{ha}$, respectively. When including both soluble and insoluble proteins, the immature plants of NC95 could yield $1387 \mathrm{~kg} / \mathrm{ha}$ of protein, in comparison to $1308 \mathrm{~kg} / \mathrm{ha}$ for $\mathrm{Ky} 14$. Multiple harvests of regrowth can further the protein yield per hectare. The present results strongly suggest that tobacco is a potential protein crop for the future.

\section{ZUSAMMENFASSUNG}

Unter den für Burley-Tabak üblichen Kulturbedingungen verlief die Akkumulation löslicher Proteine - insbesondere die von Fraktion-I- und Fraktion-II-Protein (FIund FII-Protein) - in hellem Tabak (NC95) und in Burley-Tabak (Ky14) während der Anbaujahre 1977 und 1978 ähnlich. Die Konzentrationen der FI- und FIIProteine erreichten Maximalwerte zur Blïtezeit und nahmen dann schrittweise ab. Dabei sank der Gehalt an FIProtein während der Blattreife sehr viel rascher als der an FII-Protein. Die Ergebnisse der beiden Jahre zeigten, daß Ky14 - über die Wachstumsperiode gemittelt - bedeutend mehr FI-Protein, unlösliche Proteine, Gesamt- 
eiweiß, freie Aminosäuren, Gesamtstickstoff, Nitrat-Stidkstoff und Gesamtalkaloide enthielt als NC95. NC95 besaß einen höheren Chlorophyllgehalt als Ky14. Beide Sorten unterschieden sich nicht im Gehalt an FII-Protein.

Auf Grundlage der Konzentration löslicher Proteine in der Blattlamina und einer je nach Größe der Pflanzen verdoppelten oder vervierfachten Populationsdichte wurden die Ausbeuten an löslichen Proteinen bei Ky14 im unreifen Zustand auf $888 \mathrm{~kg} / \mathrm{ha}$, etwa eine Woche vor dem Köpfen auf $470 \mathrm{~kg} / \mathrm{ha}$ und zum Erntezeitpunkt auf $281 \mathrm{~kg} / \mathrm{ha}$ geschätzt. Der Ertrag an löslichen und unlöslichen Proteinen könnte bei unreifen NC95-Pflanzen $1387 \mathrm{~kg} / \mathrm{ha}$ betragen, verglichen mit $1308 \mathrm{~kg} / \mathrm{ha}$ bei Ky14. Mehrfache Ernten des Wiederaustriebs können die Proteinausbeute pro Hektar erhöhen. Die vorliegenden Ergebnisse deuten darauf hin, daß Tabak zukünftig ein potentieller Proteinlieferant sein könnte.

\section{RESUME}

Pendant les campagnes de cultures 1977 et 1978, on a constaté une accumulation de protéines solubles, en particulier protéines Fraction I et protéines Fraction II (protéines FI et FII), analogue dans le tabac blond (NC95) et le tabac Burley (Ky14), cultivés selon la manière habituelle pour le Burley. Les concentrations en protetines FI et F II ont atteint un maximum à la floraison, puis ont diminué peu à peu. Pendant la période de maturation des feuilles, la teneur en protéines FI décrût bien plus rapidement cependant que celle en protéine FII. La comparaison des résultats obtenus durant les deux années en question, révèle qu'en moyenne le Ky14 contenait bien plus de protéines FI, de protéines insolubles, de protéines totales, d'amino-acides libres, d'azote total, d'azote-nitrate et d'alcaloïdes totaux que le NC95. Le NC95 possédait une plus forte teneur en dilorophylle que le Ky14. Les deux plantes présentaient une concentration analogue en protéine F II.

Sur la base de la concentration des protéines solubles contenues dans le limbe de la fesille et une densité de population double ou quadruple, selon la taille de la plante, on a évalué les quantités de protéines solubles contenues dans le $\mathrm{Ky} 14$ à $888 \mathrm{~kg} / \mathrm{ha}$ avant son mêrissement, à $470 \mathrm{~kg} / \mathrm{ha}$ une semaine environ avant l'écimage et $\$ 281 \mathrm{~kg} / \mathrm{ha}$ au moment de la récolte. En additionnant les protéines solubles et insolubles, on obtient un rendement de $1387 \mathrm{~kg} / \mathrm{ha}$ pour les plantes du NC95, avant mûrissement, contre $1308 \mathrm{~kg} / \mathrm{ha}$ pour le $\mathrm{Ky} 14$. On pourrait augmenter le rendement en protéines à l'hectare par récoltes multiples des regains. Les présents résultats donnent à penser que, dans l'avenir, le tabac pourrait devenir une source de protéines.

\section{REFERENCES}

1. Arnon, D. I.: Copper enzymes in isolated chloroplasts - Polyphenoloxidase in Beta vulgaris; Plant Physiol. 24 (1949) 1-15.
2. Bernstein, B. A.: Tobacco proteins - Effect of population density of planting on yield and effect of leaf age on the enzyme kinetic parameters of Fraction I protein (RUBP carboxylase); M. S. thesis, University of Kentudky, 1981, pp. 62.

3. Chan, P. H., K. Sakano, S. Singh and S. G. Wildman: Crystalline Fraction I protein: Preparation in large yield; Science 176 (1972) 1145-1146.

4. DeJong, D. W., and J. J. Lam, Jr.: Application of homogenized leaf curing to protein recovery and to the alteration of leaf chemistry for production of less hazardous tobacco; Tobacco Research 5 (1978) 1-27.

5. Ershoff, B. H., S. G. Wildman and P. Kwanyuen: Biological evaluation of crystalline Fraction I protein from tobacco; Proc. Soc. Exp. Biol. Med. 157 (1978) 626-630.

6. Harvey, W. R., H. W. Stahr and W. C. Smith: Automated determination of reducing sugars and nicotine alkaloids on the same extract of tobacco leaf; Tobacco Science 13 (1969) 13-15.

7. Kawashima, N., and S. G. Wildman: Fraction I protein; Ann. Rev. Plant Physiol. 21 (1970) 325-358.

8. Kung, S. D., and T. C. Tso: Tobacco as a potential food source and smoke material; J. Food Sci. 43 (1978) 1844-1847.

9. Lowe, R. H.: Crystallization of Fraction I protein from tobacco by a simplified procedure; FEBS Letters 78 (1977) 98-100.

10. Pimentel, D., W. Dritschilo, J. Krunmel and J. Kutzman: Energy and land constraints in food protein production; Science 190 (1975) 754-761.

11. Sheen, S. J., and R. H. Lowe: Proteins and related nitrogenous compounds in virus-infected tobacco plants; Can. J. Plant Sci. 59 (1979) 1099-1107.

12. Wildman, S. G.: Tobacco, a potential food crop; Crops and Soils Magazine, January 1979, 7-9.

13. Wildman, S. G., and J. Bonner: The proteins of green leaves; Arch. Biochem. Biophys. 14 (1947) 381-413.

\section{Adenowledgements}

The investigation reported in this paper (80-11-3-189) was in connection with a project of the Kentucky Agricultural Experiment Station, Lexington, Kentudky, and is published with the approval of the Director. The research was supported in part by the U.S. Department of Agriculture Cooperative Agreement No. 12-14-7001104-1 and the University of Kentudky Tobacco and Health Research Institute Project No. 24110.

Authors' address:

Department of Plant Pathology,

College of Agriculture,

University of Kentudey,

S-30S Ag. Science Bldg.-North,

Lexington, Kentudey, 40546,

U.S.A. 